\title{
RECOVERY OF FORMIC ACID BY REACTIVE EXTRACTION USING AN ENVIRONMENTALLY- FRIENDLY SOLVENT
}

\author{
${ }^{1}$ Mustafa Esen MARTI \\ ${ }^{1}$ Selçuk Üniversitesi, Mühendislik Fakültesi, Kimya Mühendisliği Bölümü, KONYA \\ marti@selcuk.edu.tr
}

(Geliş/Received:29.12.2016 ; Kabul/Accepted in Revised Form: 30.01.2017)

\begin{abstract}
Today many carboxylic acids are recovered from biological production media and industrial wastewaters. Reactive extraction is favored over other separation methods due to its high recovery efficiency, ease of operation, low energy demand and reduced cost. However, use of toxic organic diluents in the organic phases is the main disadvantage of the method. In this study, the appropriateness of an environmentally-friendly solvent, sunflower oil (SFO) to be used as organic phase diluent during the recovery of formic acid (FA) from aqueous solutions by reactive extraction was evaluated. Alamine-336 was used as the extractant and the results obtained with SFO were compared with those obtained using octanol. The separation process reached an equilibrium in 3 hours and the recovery efficiency increased with the increase in extractant percentages. The initial FA concentration positively influenced the recovery when SFO was used as the diluent. In the ranges of the parameters studied, the highest recovery values were $98.6 \%$ and $82.6 \%$ with octanol and SFO, respectively. This study shows that low molecular weight carboxylic acids, e.g. FA can be recovered from aqueous solutions by reactive extraction using environmentally-friendly solvents such as SFO.
\end{abstract}

Key Words: Formic acid, Reactive extraction, Sunflower oil, Alamine-336, Equilibrium

\section{Formik Asidin Çevre Dostu Bir Çözücü Kullanılarak Tepkimeli Özütleme Yöntemi ile Geri Kazanımı}

ÖZ: Günümüzde pek çok karboksilik asit biyolojik üretim ortamlarından ve endüstriyel atık sulardan geri kazanılmaktadır. Tepkimeli özütleme, yüksek geri kazanım verimi, işlem basitliği, düşük enerji gereksinimi ve maliyeti nedeniyle diğer ayırma yöntemlerine tercih edilmiştir. Fakat organik fazlarda zehirli organik seyrelticilerin kullanımı yöntemin en önemli dezavantajıdır. Bu çalışmada çevre dostu bir çözücünün, ayçiçek yağının formik asidin sulu çözeltilerinden tepkimeli özütleme yöntemi ile geri kazanımı sırasında organik faz seyrelticisi olarak zehirli organik kimyasallar yerine kullanımı değerlendirilmiştir. Özütleyici olarak Alamine-336 kullanılmış ve ayçiçek yağı ile elde edilen sonuçlar oktanol ile elde edilen sonuçlarla karşılaştırılmıştır. Ayırma süreci 3 saatte dengeye ulaşmış ve geri kazanım verimi özütleyici yüzdesi ile birlikte artmıştır. Ayçiçek yağı seyreltici olarak kullanıldığında başlangıç asit derişimi geri kazanımı pozitif yönde etkilemiştir. Çalışılan değişken aralıklarında oktanol ve ayçiçek yağı ile en yüksek geri kazanım verimleri sırasıyla \%98,6 ve \%82,6'dır. Bu çalışma formik asit gibi düşük molekül ağırlıklı karboksilik asitlerin tepkimeli özütleme ile ayçiçek yağı gibi çevre dostu çözücüler kullanılarak sulu çözeltilerden geri kazanılabileceğini göstermiştir.

Anahtar Kelimeler: Formik asit, Tepkimeli özütleme, Ayçiçek yă̆g, Alamine-336, Denge

DOI: 10.15317/Scitech.2017.67 


\section{INTRODUCTION}

Today, many biochemicals are produced by biological techniques instead of chemical synthesis methods (Straathof, 2014). Likewise, carboxylic acids can be produced as a target- or by-product by fermentation or they can also be found in industrial wastewaters (Yang et al., 2007; Rasrendra et al., 2011; Mart1 and Gürkan, 2015). However, the recovery of carboxylic acids from dilute aqueous solutions with high efficiency is still a challenging separation problem (Wasewar et al., 2004; Lopez-Garzon and Straathof, 2014; Uslu et al., 2015; Datta et al., 2016). Moreover, most of the industrial separation operations are carried out using toxic chemicals (Harington and Hossain, 2008; Keshav et al., 2009) and the cost of these processes are generally $\geq 40 \%$ of the total cost (Chen and Juang, 2008; Straathof, 2014). Therefore, several researchers from all over the world have been studying the recovery of carboxylic acids from production media and wastewaters, or aqueous solutions having similar characteristics (concentration, $\mathrm{pH}$ and etc.) to the former materials to identify promising isolation methods or procedures (Kertes and King, 1986; Wasewar et al., 2004; Uslu et al., 2015).

Despite these studies, carboxylic acids, e.g. formic acid, are still recovered by traditional methods that produce dangerous and toxic waste materials in industry. Due to the energy and environmental problems caused by this waste, the technique should be replaced by efficient, novel and environmentally-friendly alternatives. Several separation techniques such as solvent extraction, distillation, membrane filtration, electrodialysis, ion exchange and adsorption have been tested for the purpose (Mart1 2010). Reactive extraction, which is the advanced form of traditional solvent extraction method, has been favored over other techniques due to its high efficiency, ease of operation, low energy demand and cost (Kertes and King, 1986; Martı et al., 2011). Another advantage of the technique is thermal stability of the target molecule during the process (Martı and Gürkan, 2015). Different from its origin, reactive extraction can recover carboxylic acids by chemical extraction besides physical extraction. This is achieved by the extractants that are dissolved in the organic phase diluent or solvent and have the ability to react with the target material. With the help of this, the recovery efficiencies notably increase and the separations carried out in multiple steps can be achieved in a single stage (Mart1, 2016).

Long chain aliphatic amines and organophosphoric compounds are known to the most efficient extractants for the recovery of carboxylic acids from aqueous solutions. In particular, tertiary amines and their mixtures have been successfully used for the recovery of several types of carboxylic acids (Tamada et al., 1990; Martı et al., 2011; Lopez-Garzon and Straathof, 2014; Uslu et al., 2015). The tertiary amines form acid-amine complexes with the undissociated form of the target acid in the organic phase during the reactive extraction process. Another advantage of the use of tertiary amines is their ease of regeneration and re-uses in the consecutive recovery operations (Gorden et al., 2016; Reyhanitash et al. 2016).

In general, water-immiscible organic solvents that can dissolve the extractants are used as the diluents during the organic phase preparations. For an industrial application, the organic phase should have operational properties such as viscosity and concentration that are mostly influenced by the diluent. The diluent also promotes the reaction between the acid and amine during the transfer. Thus, it directly influences the stability and solubility of the complex structures that also affect the recovery efficiency. Mostly alcohols, alkanes and ketones are used as the organic phase diluents in the reactive extraction of carboxylic acids (King and Kertes, 1986; Tamada et al., 1990; Martı, 2010; Uslu et al., 2015; Datta et al., 2016).

However, high toxicity and the cost of the solvents (diluent) used during the preparation of the organic phase are the most important disadvantages of the reactive extraction technique. Solving this problem will make the process be environmentally-friendly and economic. Attempts to eliminate this problem have been cited in the literature (Harington and Hossain 2008; Keshav et al. 2009; Wasewar et al., 2011; Waghmare et al., 2011; Keshav et al., 2012; Waghmare et al., 2013; Uslu et al., 2014). 
Harington and Hossain (2008) selectively recovered lactic acid with an initial concentration of 0.2-0.3 $\mathrm{M}$ from biological production media by reactive extraction. The authors used tributylphosphate (TBP) and sunflower oil (SFO) as the diluents, and trioctylamine (TOA) and Aliquat 336 (trioctylmethylammoniumchloride, TOMAC) as the extractants. The researchers investigated the effects of aqueous phase $\mathrm{pH}$, organic phase constituents and temperature on the recovery. Highest extraction efficiency was achieved with the organic phase containing 15\% TOA + 15\% Aliquat 336 + 35\% TBP + 35\% SFO. This extracted $70 \%$ of the lactic acid, which was recoverable from the organic phase to a second aqueous phase containing of sodium carbonate (Harington and Hossain, 2008).

Keshav and co-workers (2009) studied the recovery of propionic acid from aqueous solutions using TBP / Aliquat 336 / TOA as extractants dissolved in SFO. In addition, they modified the organic phase using active organic solvents and modifiers. Decanol was reported to be the most efficient modifier among those tested. They achieved the highest recovery with 20\% Aliquat 336 (Keshav et al. 2009). In another study, the same researchers extracted citric acid by using TOA as an extractant, which they dissolved in non-toxic diluents: soy, sesame, sunflower and rice bran oil. They obtained more than $90 \%$ extraction efficiency with all organic phases studied. Rice-bran oil was the most efficient among those evaluated. The researchers calculated the equilibrium constant and loading ratio for each organic phase system (Keshav et al., 2012).

Wasewar et al. (2011) used TBP or Aliquat 336 dissolved in SFO to recover itaconic acid from aqueous solutions by reactive extraction. The researchers compared the results obtained with two different extractants and determined the equilibrium constants for the acid-amine complexes formed in the organic phases (Wasewar et al., 2011).

In another study, Waghmare and co-workers (2011) compared SFO and castor oil for extracting picolinic acid, using TBP as the extractant. Castor oil provided higher recovery efficiencies compared to SFO (Waghmare et al. 2011). The same researchers used TBP and soy oil in a follow-up study to extract picolinic- and nicotinic acids from aqueous solutions. Their results indicated higher recoveries for picolinic acid as the highest extraction percentage with picolinic acid was $27.22 \%$, while that with nicotinic acid was 6.99\% (Waghmare et al., 2013).

Uslu and co-workers (2014) extracted fumaric acid by using tridodecylamine (TDDA) and tributylamine (TBA) as the extractants, with canola, sesame and almond oil as the organic phase diluents. They compared the extraction efficiencies and loading ratios for each system and tried to identify the best organic phase members for the process to maximize recoveries. The results obtained with the two amine extractants were similar to each other; canola oil was superior to the other oils studied (Uslu et al. 2014).

These studies show that there is no exact trend for the reactive extraction systems using vegetable oils as the organic phase diluents. None of the extractants and vegetable oils tested were shown to be superior to the others for all conditions, acids and extractants. Thus, considerable testing is still required. For example, there is no study on the recovery of formic acid using environmentally-friendly solvents, e.g. vegetable oils, nor are there studies in the literature comparing the results obtained with vegetable oils and an organic solvent, e.g. octanol.

In this study, formic acid (FA) was recovered by using the non-toxic diluent, sunflower oil (SFO), instead of organic solvents, previously described in the literature (Şenol, 2000; Qin et al., 2003; İnce et al., 2007; Uslu, 2009; Martı and Oflaz, 2013). This is the first report of the successful use of this extraction strategy on FA. Formic acid is the simplest carboxylic acid and used as preservative and anti-bacterial agent in food and pharmaceutical applications (Cai et al., 2001). Moreover, it is widely used in tanning, coloring and cleaning steps of leather and textile industries (Martı and Oflaz, 2013). It is reported that FA is present in several types of industrial wastewaters (Rasrendra et al., 2011) and has the potential to cause environmental problems. Therefore, its removal or recovery from aqueous streams is needed.

The experimental results obtained with SFO were compared with those obtained with octanol. Alamine-336 (ALA-336), a mixture of long chain aliphatic amines, was chosen as the extractant in the study. This extractant was previously used with several reactive extraction systems (San Martin et al., 
1992; İnci et al., 2000; Wasewar et al., 2002). Besides the evaluation of the SFO for FA recovery, the effects of contact time, initial concentrations of acid and extractant on the recovery were also investigated.

\section{MATERIAL AND METHODS}

Formic acid and octanol were obtained from Merck Co., while ALA-336 (containing >95\% TOA) was from Cognis Co. Sunflower oil (Zade) was obtained from local markets. All chemicals and SFO were used without any pretreatment. Deionized water (UHP) obtained from a Millipore Milli-Q system was used in the experiments. The aqueous phases were prepared by dissolving FA in UHP water at predetermined concentrations. Initial acid concentrations were varied between $0.2-$ and $1.0 \mathrm{M}$ to reflect their concentrations in biological production media and wastewaters.

Prior to the reactive extraction studies, physical extraction experiments were carried out. These organic phases did not contain any extractant. This enabled the determination of the extractability of FA by the diluent, which was used during the calculation of the amount of acid reacted with the extractant (Tamada et al., 1990; Wasewar et al., 2002; Martı et al., 2011). The organic phases used in reactive extraction experiments were prepared by dissolving ALA-336 (10-50\% v/v) in octanol or SFO (Hossain and Harington, 2008; Keshav et al., 2009; Waghmare et al., 2013).

Equal volumes $(5 \mathrm{~mL})$ of organic and aqueous phases were equilibrated by shaking for $4 \mathrm{~h}$ at $25^{\circ} \mathrm{C}$ using a constant temperature shaker bath (Jeiotech). Preliminary studies showed that this time is sufficient for reaching equilibrium. Following that, the mixture was centrifuged for 10 minutes at 6000 rpm and settled for 15 minutes. A clear phase separation was obtained and a sample of the aqueous phase was carefully removed with a pipet for analysis of solute concentration. The amount of FA in the aqueous phase before and after the extraction was determined by acid-base titration. Sodium hydroxide and phenolphthalein were used as the titrant and indicator, respectively, during the analyses. Since FA is a monocarboxylic acid, Equation 1 (E-1) was used to calculate the amount of acid in the aqueous phase.

$$
\mathrm{M}_{\text {Acid }} \times \mathrm{V}_{\text {Acid }}=\mathrm{M}_{\mathrm{NaOH}} \times \mathrm{V}_{\mathrm{NaOH}}
$$

The amount of FA extracted into the organic phase was determined by a mass balance around the aqueous phase. The experimental results were used to evaluate the efficiency of the extraction process using the equilibrium data and the equations below. The extraction efficiency $(E \%)$ and distribution coefficient $\left(K_{D}\right)$ were calculated using E-2 and E-3, respectively. To estimate the stoichiometry of the acid-amine complex in the organic phase, the loading ratio $(z)$ was calculated (E-4).

$$
\begin{aligned}
& E \%=\mathrm{C}_{\mathrm{FA}, \text { org }} / \mathrm{C}_{\mathrm{FA}, \text { total }} \times 100 \\
& K_{\mathrm{D}}=\mathrm{C}_{\mathrm{FA}, \text { org }} / \mathrm{C}_{\mathrm{FA}, \text { aq. }} \\
& z=\mathrm{C}_{\mathrm{FA}, \text { org. }} / \mathrm{C}_{\mathrm{ALA}-33, \text { total }}
\end{aligned}
$$

All experiments and analyses were replicated twice and average values were used to calculate the extraction parameters. Experimental error was found to be $\leq 1 \%$ in the studies.

\section{RESULTS AND DISCUSSION}

\section{Effect of Contact Time}

It is important to determine the equilibration time for a process that will be integrated into industrial productions, as it can directly affect several parameters including energy and efficiency (Martı et al., 2011). Therefore, prior to the equilibrium experiments, kinetic studies were carried out to estimate the equilibration period. An aqueous solution of 0.63 M FA was used in these experiments. As can be seen in 
Figure 1, all systems reached equilibrium in 3 hours. Thus, all equilibrium experiments were carried out at $298 \mathrm{~K}$ and constant agitation speed $(150 \mathrm{rpm})$ for four hours to insure consistent results.

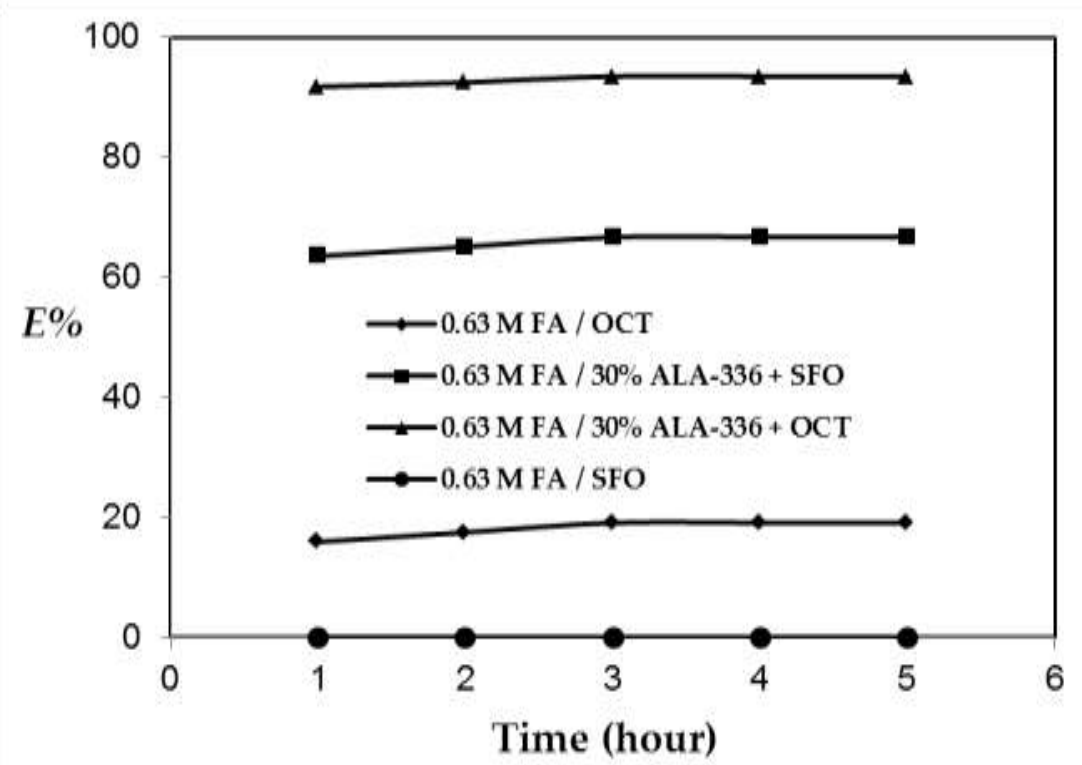

Figure 1. Effect of contact time on the physical- and reactive extraction of formic acid (Kinetic data).

\section{Physical Extraction}

Recovery values obtained with organic phases containing only solvents (without extractants) are shown in Figure 1. According to the data, extraction efficiency obtained with the reference organic solvent, octanol was about $19 \%\left(K_{\mathrm{D}}=0.23\right)$. On the other hand, almost no FA could be extracted from the aqueous phase with SFO. The most important reason for this result is the relatively high polarity of alcohols with intermediate molecular weights. In general, water immiscible organic compounds have low polarity values and this makes them inappropriate for the recovery of polar materials, e.g. carboxylic acids. However, intermediate molecular weight alcohols such as octanol are relatively polar organic chemicals, giving them a significant advantage for the recovery of carboxylic acids.

As shown in Figure 1, the extraction efficiency obtained with octanol was only 19\%. This is consistent with the results reported in the literature for different systems (Mart1 et al., 2011; Mart1, 2016, Mart1 et al., 2016). Due to the weak interactions, the recovery with physical extraction is not efficient and necessitates repetitive extraction processes or the use of extraction columns including several steps (Tamada et al., 1990). For example, to recover $90 \%$ of the FA, either the extraction process should be repeated 11 times or an extraction column with 11 stages is needed, thus making the process inefficient and costly. Therefore, the process should be improved using an external parameter to increase the efficiency of the extraction. The addition of chemical extraction is an advantageous alternative to facilitate the process.

\section{Effect of Extractant Concentration}

As previously stated, reactive extraction is the advanced form of traditional liquid-liquid extraction processes. The literature shows that the use of chemical extraction or the presence of an extractant in the organic phase significantly increases the efficiency of the recovery (Kertes and King, 1986; Wasewar et al., 2004; Uslu et al., 2015). However, the high toxicity of these organic solvents is a major disadvantage of the reactive extraction technique. Therefore, environmentally-friendly solvents or diluents should be explored. Vegetable oils are important alternatives with their chemistry (composition and structure) and water immiscibility. Even if they cannot extract the acids from the aqueous phase by themselves (by 
physical means); their availability for the reactive extraction operations should be tested by equilibrium studies.

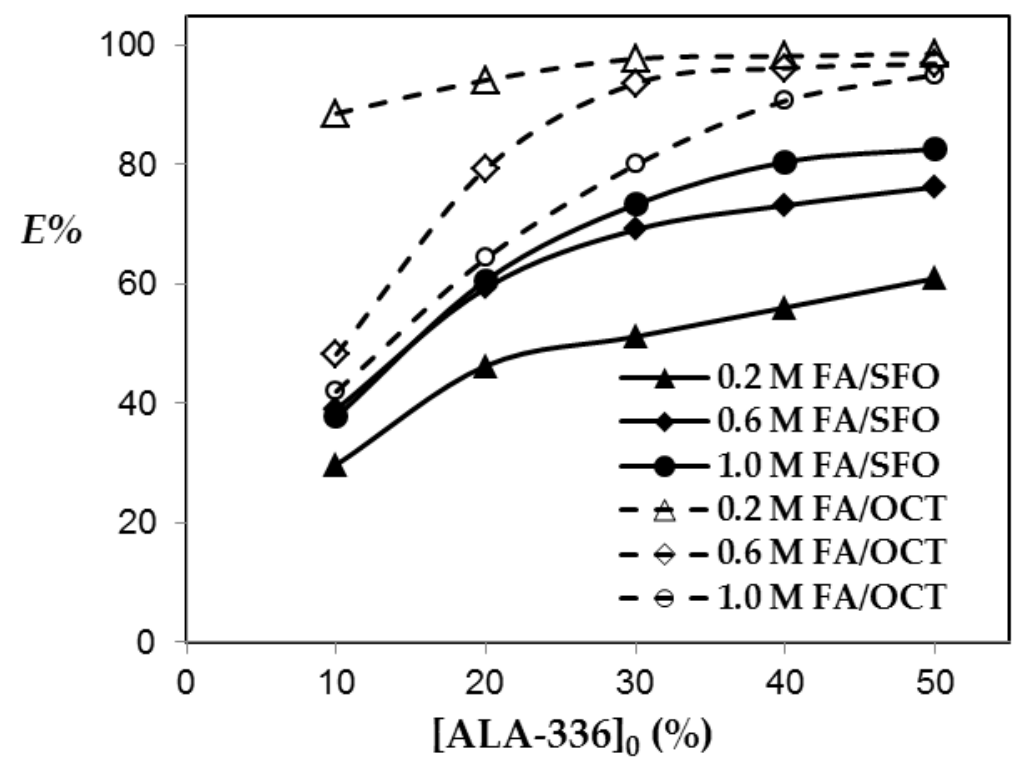

Figure 2. Effect of initial extractant percentage on extraction efficiency of formic acid by reactive extraction.

Figure 2 shows the influence of ALA-336 and its initial amount (\% v/v) on the recovery of FA. As shown (Fig. 1), the recovery efficiency was $19 \%\left(K_{D}=0.23\right)$ when octanol was the sole component in the organic phase, and the initial FA concentration was about $0.6 \mathrm{M}$. Adding $10 \%$ (v/v) ALA-336 to the octanol increased the extraction efficiency to $48.25 \%\left(K_{\mathrm{D}}=0.93\right)$. The impact of ALA-336 was higher at lower initial acid concentrations. On the other hand, at the same ALA-336 level and FA concentration, the recovery efficiency was $39 \%\left(K_{D}=0.64\right)$ with SFO. Thus, the use of chemical extraction significantly increased the efficiency from $\sim 0 \%$ to $39 \%$ and facilitated the FA transfer. This result also shows that SFO provides an appropriate media for the acid-amine reaction and that it is a proper diluent for the reactive extraction of FA.

Figure 2 also shows that the extraction efficiency increased with the increase in extractant percentage in the organic phase, which is consistent with the literature (Mart1 et al. 2011, Datta et al. 2016). When the acid- and ALA-336 concentrations were $0.6 \mathrm{M}$ and 30\%, respectively, the recovery efficiencies obtained with octanol and SFO were $93.65 \%\left(K_{\mathrm{D}}=14.75\right)$ and $69.15 \%\left(K_{\mathrm{D}}=2.24\right)$, respectively. The positive effect increased with the increase in extractant concentration. At the same acid concentration, $50 \%(\mathrm{v} / \mathrm{v})$ ALA336 provided $96.9 \%\left(K_{\mathrm{D}}=31.3\right)$ and $76.25 \%\left(K_{\mathrm{D}}=3.21\right)$ recovery with octanol and $\mathrm{SFO}$, respectively. The highest extraction efficiency obtained with SFO was $82.6 \%\left(K_{\mathrm{D}}=4.78\right)$ at $1.0 \mathrm{M} \mathrm{FA}$, while that with octanol was $98.6 \%\left(K_{\mathrm{D}}=70.7\right)$ at $0.2 \mathrm{M} \mathrm{FA}$. The results exhibit that $\mathrm{SFO}$ has the potential to provide higher efficiency values at higher extractant percentages.

It is seen that the effect of extractant concentration was influenced from initial acid amount and the trends were different for both diluents (Figure 2). For example at 10\% ALA-336, the recovery with $0.2 \mathrm{M}$ FA was much higher than that with the other FA concentration levels in octanol. With the increase in extractant concentration, even the results with $0.2 \mathrm{M}$ FA were superior to the others; the difference became small and almost disappeared at 50\% ALA-336 level in octanol. Regardless of the initial FA concentration, more than $95 \%\left(K_{\mathrm{D}} \geq 19\right)$ recovery was achieved with $50 \%(\mathrm{v} / \mathrm{v})$ ALA-336 in octanol. On the other hand, a different trend was observed with SFO. The recoveries for varied FA concentrations are close to each other at 10\% (v/v) ALA-336 in SFO. With the increase in initial percentage of the extractant in the organic phase, the difference between the results became greater. The influence could be observed 
at $30 \%$ extractant level. The results with 0.6 and $1.0 \mathrm{M} \mathrm{FA}$ were relatively close to each other, but much higher than that with 0.2 at $30-50 \%$ (v/v) ALA-336 levels.

As can be seen, the results obtained with SFO are acceptably high and close to those obtained with octanol. In addition, the results also showed that higher or desired recovery efficiencies could also be obtained with SFO with the right selection of extractant type and concentration. This will enable the replacement of toxic organic chemicals with environmentally-friendly diluents for extractive separations.

\section{Effect of Acid Concentration}

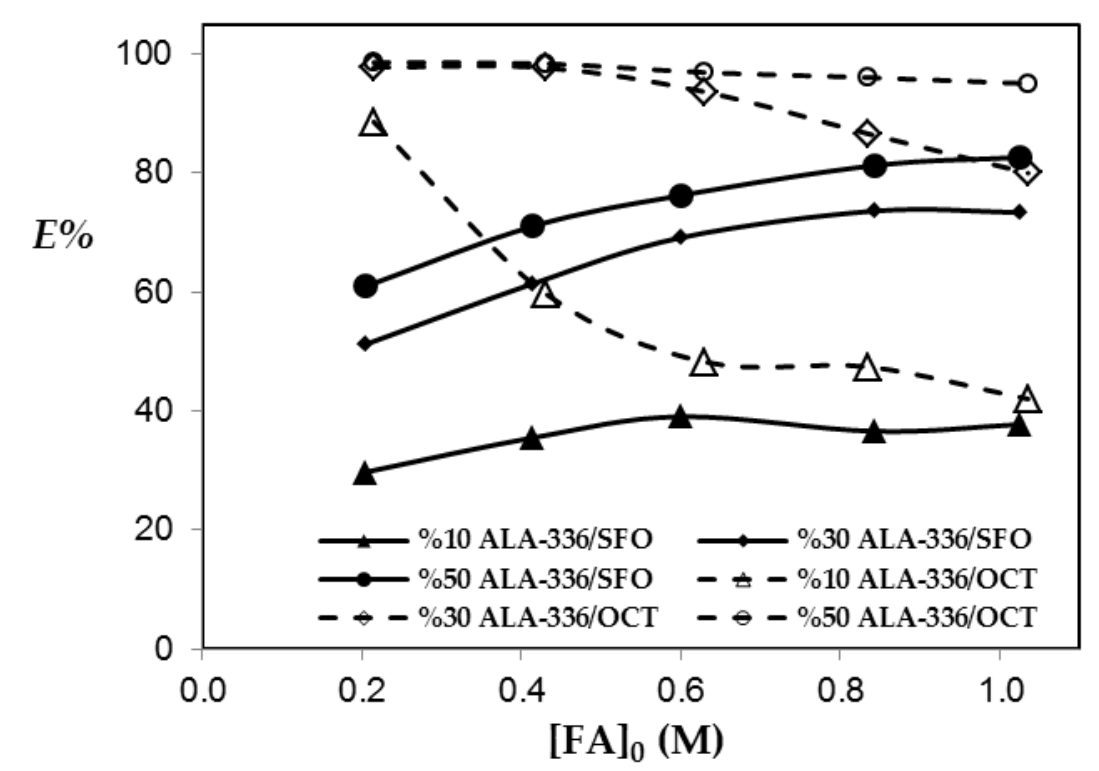

Figure 3. Variation of extraction efficiency with the initial acid concentration for the reactive extraction of formic acid.

Another important parameter affecting the success of a reactive extraction system is the initial amount of acid present in the aqueous phase. It was shown that the recovery with reactive extraction was significantly influenced by the concentration and type of the acid (Gu et al., 1998; Mart1 et al., 2011; Martı and Gürkan, 2015).

Figure 3 shows that the recovery efficiencies were influenced in different ways by initial FA concentrations when octanol or SFO was selected as the organic phase diluent. With octanol, the extraction efficiency decreased as acid concentration increased. The trend was obvious with $10 \% \mathrm{v} / \mathrm{v}$ ALA-336. At this level, the recovery efficiency was $88.6 \%\left(K_{\mathrm{D}}=7.78\right)$ for $0.2 \mathrm{M} \mathrm{FA}$; at $1.0 \mathrm{M}$ initial FA, recovery was only $42 \%\left(K_{D}=0.73\right)$.

This trend was observed to disappear at higher ALA-336 percentages. At FA molarities of 0.2- and 0.4 , recovery efficiencies with $30 \%$ - and $50 \%$ ALA-336 were identical or nearly same $\left(\sim 98 \%, K_{D} \sim 50\right)$, and the efficiency losses were insignificant at these ALA-336 percentages. Under these conditions, the initial ALA-336 concentrations were higher than those of FA and the results indicated that almost all acids were extracted by the organic phase or the organic phase diluent was at- or very near saturation for the FA:ALA-336 complexes. At higher FA concentrations $(>0.6 \mathrm{M})$, the efficiency varied inversely with ALA336 percentages. When initial FA concentration was $1.0 \mathrm{M}$, the extraction efficiency was $95 \%\left(K_{\mathrm{D}}=19\right)$ with $50 \%$ ALA-336 but only $80 \%$ (KD 4) with 30\% ALA-336.

On the other hand, an opposite trend was observed when SFO was used as the diluent. In the ranges of the parameters, the recovery efficiencies obviously increased with the increase in FA concentration, which continued until a FA concentration of $0.8 \mathrm{M}$ level. The success of the extraction obtained with 1.0 $\mathrm{M}$ was close to that with $0.8 \mathrm{M}$ FA. The recovery values obtained with $30 \%$ ALA-336 were closer to those 
obtained with 50\% ALA-336 compared to 10\% ALA-336. This was valid for almost all FA concentrations. The results obtained for the investigation of the acid concentration effect were consistent with the literature (Tamada et al., 1990; Gu et al., 1998; Keshav et al., 2009; Martı et al., 2011; Uslu et al., 2014; Mart1 et al., 2016).

\section{Stoichiometry}

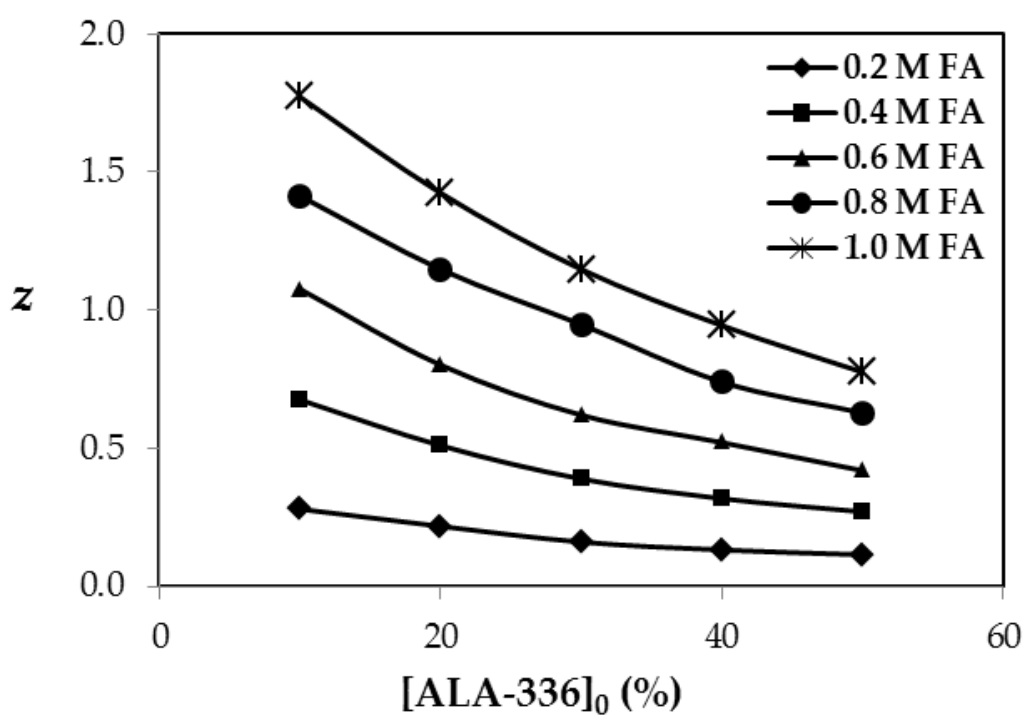

Figure 4. Loading ratios for the reactive extraction of formic acid using sunflower oil as organic phase diluent.

The stoichiometry of the acid-amine complex in the organic phase was estimated using loading ratio (z) values. Data from the literature show that the loading ratio is notably influenced by solvent type (Tamada et al., 1990; Wasewar et al., 2004). Firstly, a 1:1 acid-amine complex forms in the organic phase during the reactive extraction process. Depending on the media, conditions and the solutes present, different types of complex structures may form. Previously, the loading ratios for FA/tertiary amines/organic solvents were calculated (Şenol, 2000; Qin et al., 2003; İnce et al., 2007; Uslu, 2009)

Figure 4 shows the $\mathrm{z}$ values for reactive extraction of FA using SFO as the diluent in the organic phase. During the calculations, molar concentration values were used (E-4). Initial or total ALA-336 concentrations were varied between $0.22 \mathrm{M}(10 \% \mathrm{v} / \mathrm{v})$ and $1.09 \mathrm{M}(50 \% \mathrm{v} / \mathrm{v})$. Equilibrium concentration of FA in the organic phase changed between 0.061 - and $0.847 \mathrm{M}$.

The results showed that $\mathrm{z}$ values were markedly influenced by acid and extractant concentrations. When the initial amount of ALA-336 was $40-50 \%(\mathrm{v} / \mathrm{v})$, the $\mathrm{z}$ values were lower than unity regardless of the initial amount of acid. At lower ALA-336 percentages and acid concentrations equal and lower than $0.6 \mathrm{M}$, again the $\mathrm{z}$ values were almost equal or lower than 1 . This indicates that under these conditions, only a 1:1 type acid-amine complex formed in the organic phase. However, at the same extractant levels and higher FA concentrations, the $\mathrm{z}$ values varied between 1 and 2 , indicative of the simultaneous presence of 2:1 and 1:1 type acid-amine complexes. The results are consistent with those reported in the literature for tertiary amines and carboxylic acids (Tamada et al., 1990; Wasewar et al., 2002; Qin et al., 2003; Uslu, 2009; Martı et al., 2011)

\section{CONCLUSION}

Solvent or diluent type used during reactive extraction is so important for the recovery of carboxylic acids (Kertes and King, 1986). However, the most effective solvents are generally toxic chemicals and 
this is the most critical disadvantage of the technique that prevents its widespread use in industries. Hence, environmentally-friendly alternatives that can be used in reactive extraction processes should be explored. Evaluating these diluents should be done by the comparison with the most commonly used organic diluents. This will facilitate widespread use of the method and prevent/reduce the release of toxic chemicals from extractive separations.

In this study, sunflower oil was evaluated for use in recovering formic acid by reactive extraction to replace traditional organic solvents such as octanol. Recoveries obtained with SFO were compared with those observed with octanol, which is known to be one of the most effective diluents for the recovery of carboxylic acids. The kinetic data showed that at least 3 hours was required to reach the equilibrium for both physical- and reactive extraction. The physical extraction efficiency was about $19 \%\left(K_{\mathrm{D}}=0.23\right)$ with octanol while no FA was extracted with SFO alone.

The addition of the extractant positively influenced the recovery for both octanol and SFO. The recovery increased with the increase in initial ALA-336 percentage, and was observed for both diluents. The increase in initial concentration of FA negatively influenced the recovery with octanol while extraction efficiency increased with this parameter when SFO was used as the diluent in the organic phase. The results are consistent with the literature (Keshav et al., 2009; Waghmare et al., 2011; Uslu et al., 2014). The highest recovery values were obtained as $98.6 \%\left(K_{D}=70.7\right)$ and $82.6 \%\left(K_{D}=4.78\right)$ for octanol and SFO, respectively, at the highest ALA-336 level $(50 \% \mathrm{v} / \mathrm{v})$ studied. The results showed that the recovery efficiencies could be further increased by increasing the initial ALA-336 concentration. With the help of the loading ratios, the stoichiometry of the acid-amine complexes in the diluents was estimated to be $1: 1$ and $2: 1$.

The results showed that the recovery efficiencies with SFO were acceptably high and close to those obtained with octanol. The results also showed that with the right selection of extractant type and concentration, the desired recovery efficiencies could be achieved with SFO diluent. This will enable the replacement of toxic organic toxic chemicals with environmentally-friendly solvents for the extractive separations of carboxylic acids.

\section{ACKNOWLEDGEMENT}

The author wishes to acknowledge Selçuk University for the funding through the Scientific Research Projects (BAP) Coordination Unit under the Grant Number 16201042.

\section{LIST OF ABBREVIATIONS}

$\begin{array}{ll}\text { ALA-336 } & \text { Alamine-336 } \\ \text { CALA-336 }_{\text {A }} & \text { Concentration of Alamine-336 } \\ \text { CFA }_{\text {FA }} & \text { Concentration of formic acid } \\ \text { E\% } & \text { Extraction (Recovery) efficiency (percentage) } \\ \text { FA } & \text { Formic acid } \\ K_{D} & \text { Distribution coefficient } \\ \text { MAcid }_{\text {MNaOH }} & \text { Molarity of acid } \\ \text { OCT } & \text { Molarity of NaOH (base) } \\ \text { SFO } & \text { Octanol } \\ \end{array}$




$\begin{array}{ll}\text { VAcid } & \text { Volume of acid } \\ \text { VNaOH } & \text { Volume of NaOH (base) } \\ \text { TOA } & \text { Trioctylamine } \\ z & \text { Loading ratio } \\ \text { org. } & \text { Organic phase } \\ \text { aq. } & \text { Aqueous phase } \\ \text { total } & \text { Total concentration of formic acid or Alamine-336 in the system }\end{array}$

\section{REFERENCES}

Cai, W., Zhu, S., Piao, X., 2001, "Extraction Equilibria of Formic And Acetic Acids from Aqueous Solution by Phosphate Containing Extractants", Journal of Chemical and Engineering Data, Vol. 46, pp. 1472-1475.

Chen, H. L., Juang, R. S., 2008, "Recovery and Separation of Surfactin from Pretreated Fermentation Broths by Physical and Chemical Extraction", Biochemical Engineering Journal, Vol. 38 (1), pp. 39-46.

Datta, D., Martı, M. E., Uslu, H., Kumar, S., 2016, “Extraction of Levulinic Acid Using Tri-n-butyl Phosphate and Tri-n-octylamine in 1-octanol: Column Design", Journal of the Taiwan Institute of Chemical Engineers, Vol. 66, pp. 407-413.

Gorden, J., Zeiner, T., Sadowski, G., Brandenbusch, C., 2016, “Recovery of Cis, Cis-muconic Acid from Organic Phase After Reactive Extraction", Separation and Purification Technology, Vol. 169, pp. 18.

Gu, Z., Glatz, B. A., Glatz, C. E., 1998, “Propionic Acid Production by Extractive Fermentation. I. Solvent Considerations", Biotechnology and Bioengineering, Vol. 57 (4), pp. 454-461.

Harington, T., Hossain, Md. M., 2008, "Extraction of Lactic Acid into Sunflower Oil and Its Recovery into An Aqueous Solution", Desalination, Vol. 218, pp. 287-296.

İnce, E., Kırbaşlar, Ş. İ., Şahin, S., 2007, “Liquid-liquid Equilibria for Ternary Systems of water+formic acid+dibasic Esters", Journal of Chemical and Engineering Data, Vol. 52 (5), pp. 1889-1893.

İnci, İ., Hasdemir, M., Bilgin, M., Aydın, A., 2000, “Laktik Asitin Alamin-336 ile Çeşitli Seyreltici Çözücüler Kullanılarak Ekstraksiyonunun İncelenmesi", Turkish Journal of Engineering and Environmental Sciences, Vol. 24, pp. 45-51.

Kertes, A. S., King, C. J., 1986, "Extraction Chemistry of Fermentation Product Carboxylic Acids", Biotechnology and Bioengineering, Vol. 28 (2), pp. 269-282.

Keshav, A., Wasewar, K. L., Chand, S., 2009, "Reactive Extraction of Propionic Acid using Tri-nOctylamine, Tri-n-butyl Phosphate and Aliquat 336 in Sunflower Oil as Diluent", Journal of Chemical Technology and Biotechnology, Vol. 84 (4), pp. 484-489.

Keshav, A., Norge, P., Wasewar, K. L., 2012, "Reactive Extraction of Citric Acid Using Tri-n-octylamine in Nontoxic Natural Diluents: Part 1-Equilibrium Studies from Aqueous Solutions", Applied Biochemistry and Biotechnology, Vol. 167 (2), pp. 197-213.

Lopez-Garzon, C. S., Straathof, A. J., 2014, "Recovery of Carboxylic Acids Produced by Fermentation", Biotechnology Advances, Vol. 32 (5), pp. 873-904.

Mart1, M. E., 2010, Reactive Extraction of Pyruvic Acid From Aqueous Single and Mixed Acid Solutions, PhD Thesis, Middle East Technical University, Graduate School of Natural and Applied Sciences, Ankara.

Martı, M. E., Gürkan, T., Doraiswamy, L. K., 2011, "Equilibrium and Kinetic Studies for Reactive Extraction of Pyruvic Acid with Trioctylamine in 1-octanol", Industrial and Engineering Chemistry Research, Vol. 50 (23), pp. 13518-13525 
Martı, M. E., Oflaz, K., 2013, “Formik Asidin Alamıne-336 Ve Çeşitli Çözücülerle Tepkimeli Özütlenmesi", Selçuk Üniversitesi Mühendislik, Bilim ve Teknoloji Dergisi, Vol. 1 (3), pp. 1-8.

Martı, M. E., Gürkan, T., 2015, "Selective Recovery of Pyruvic Acid From Two and Three Acid Aqueous Solutions by Reactive Extraction", Separation and Purification Technology, Vol. 156 (2), pp. 148157.

Mart1, M. E., Zeidan, H., Uslu, H., 2016, “Reactive Extraction of Pimelic (heptanedioic) Acid from Dilute Aqueous Solutions Using Trioctylamine in decan-1-ol", Fluid Phase Equilibria, Vol. 417, pp. 197202.

Mart1, M. E., 2016, "Solvent Modification Effect on The Physical And Chemical Extraction of Acetic Acid", Separation Science and Technology, Vol. 51 (11), pp. 1806-1816.

Qin, W., Li, Z., Dai, Y., 2003, "Extraction of Monocarboxylic Acids With Trioctylamine: Equilibria and Correlation of Apparent Reactive Equilibrium Constant", Industrial and Engineering Chemistry Research, Vol. 42 (24), pp. 6196-6204.

Rasrendra, C. B., Girisuta, B., Van de Bovenkamp, H. H., Winkelman, J. G. M., Leijenhorst, E. J., Venderbosch, R. H., Windt, M., Heeres, H. J., 2011, "Recovery of Acetic Acid from an Aqueous Pyrolysis Oil Phase by Reactive Extraction Using Tri-n-octylamine", Chemical Engineering Journal, Vol. 176-177, pp. 244-252.

Reyhanitash, E., Zaalberg, B., Kersten, S. R. A., Schuur, B., 2016, “Extraction of Volatile Fatty Acids from Fermented Wastewater", Separation and Purification Technology, Vol. 161, pp. 61-68.

San-Martin, M., Pazos, C., Coca, J., 1992, "Reactive Extraction of Lactic Acid with Alamine-336 in The Presence of Salts and Lactose", Journal of Chemical Technology and Biotechnology, Vol. 54 (1), pp. $1-6$.

Straathof, A. J. J., 2014, "Transformation of Biomass into Commodity Chemicals Using Enzymes or Cells" Chemical Reviews, Vol. 114 (3), pp. 1871-1908.

Şenol, A., 2000, "Extraction Equilibria of Formic and Levulinic Acids Using Alamine 308/Diluent and Conventional Solvent Systems", Separation and Purification Technology, Vol. 21 (1-2), pp. 165179.

Tamada, J. A., Kertes, A. S., King, C. J., 1990, “Extraction of Carboxylic Acids with Amine Extractants. 1. Equilibria and Law of Mass Action Modeling", Industrial and Engineering Chemistry Research, Vol. 29 (7), pp. 1319-1326.

Uslu, H., 2009, "Reactive Extraction of Formic Acid by Using Tri octyl amine (TOA)", Separation Science and Technology, Vol. 44 (8), pp. 1784-1798.

Uslu, H., Gemici, A., Gök, A., Kırbaşlar, İ., 2014, “Reactive Extraction of (E)-butenedioic Acid (fumaric acid) by Nontoxic Diluents", Journal of Chemical and Engineering Data, Vol. 59 (11), pp. 3767-3772.

Uslu, H., Yankov, D., Wasewar, K. L., Azizian, S., Ullah, N., Ahmad, W., 2015, “Separation of Organic and Inorganic Compounds for Specific Applications" Journal of Chemistry, Vol. 2015, Article ID: 698259, pp. 1-3.

Waghmare, M. D., Wasewar, K. L., Sonawane, S. S., Shende, D. Z., 2011, “Natural Nontoxic Solvents for Recovery of Picolinic Acid by Reactive Extraction", Industrial and Engineering Chemistry Research, Vol. 50 (23), pp. 13526-13537.

Waghmare, M. D., Wasewar, K. L., Sonawane, S. S., Shende, D. Z., 2013, “Reactive Extraction of Picolinic and Nicotinic Acid by Natural Non-toxic Solvent", Separation and Purification Technology, Vol. 120, pp. 296-303.

Wasewar, K. L., Heesink, B. M., Versteeg, G. F., Pangarkar, V. G., 2002, “Reactive Extraction of Lactic Acid Using Alamine-336 in MIBK: Equilibria and Kinetics", Journal of Biotechnology, Vol. 97 (1), pp. 59-68.

Wasewar, K. L., Yawalkar, A. A., Moulijn, J. A., Pangarkar, V. G., 2004, “Fermentation of Glucose to Lactic Acid Coupled With Reactive Extraction: A review", Industrial and Engineering Chemistry Research, Vol. 43 (19), pp. 5969-5982. 
Wasewar, K. L., Shende, D., Keshav, A., 2011, "Reactive Extraction of Itaconic Acid Using Tri-n-butyl Phosphate and Aliquat 336 in Sunflower Oil as A Non-toxic diluent", Journal of Chemical Technology and Biotechnology, Vol. 86 (2), pp. 319-323.

Yang, S. T., Huang, H., Tay, A., Qin, W., De Guzman, L., San Nicolas, C., 2007, Extractive Fermentation for The Production of Carboxylic Acids, S. T. Yang (Ed.), Bioprocessing for value-added products from renewable resources: New technologies and applications, 1. Edition, Elsevier, New York, pp. 421. 